\title{
Characterization of satellite-based proxies for estimating nucleation mode particles over South Africa
}

\author{
A.-M. Sundström ${ }^{1}$, A. Nikandrova ${ }^{1}$, K. Atlaskina ${ }^{1}$, T. Nieminen ${ }^{1}$, V. Vakkari $^{2,1}$, L. Laakso ${ }^{2,3}$, J. P. Beukes ${ }^{3}$, A. Arola ${ }^{4}$, \\ P. G. van $\mathrm{Zyl}^{3}$, M. Josipovic ${ }^{3}$, A. D. Venter ${ }^{3}$, K. Jaars ${ }^{3}$, J. J. Pienaar ${ }^{3}$, S. Piketh ${ }^{3}$, A. Wiedensohler ${ }^{5}$, E. K. Chiloane ${ }^{3,6}$, \\ G. de Leeuw ${ }^{2}$, and M. Kulmala ${ }^{1}$ \\ ${ }^{1}$ Department of Physics, University of Helsinki, Helsinki, Finland \\ ${ }^{2}$ Finnish Meteorological Institute, Helsinki, Finland \\ ${ }^{3}$ Unit for Environmental Science and Management, North-West University, Potchefstroom, South Africa \\ ${ }^{4}$ Finnish Meteorological Institute, Kuopio, Finland \\ ${ }^{5}$ Leibniz Institute for Tropospheric Research, Leipzig, Germany \\ ${ }^{6}$ Eskom Holdigns SOC Ltd, Sustainability Division, South Africa
}

Correspondence to: A.-M. Sundström (anu-maija.sundstrom@helsinki.fi)

Received: 8 August 2014 - Published in Atmos. Chem. Phys. Discuss.: 14 October 2014

Revised: 6 March 2015 - Accepted: 6 April 2015 - Published: 4 May 2015

\begin{abstract}
Proxies for estimating nucleation mode number concentrations and further simplification for their use with satellite data have been presented in Kulmala et al. (2011). In this paper we discuss the underlying assumptions for these simplifications and evaluate the resulting proxies over an area in South Africa based on a comparison with a suite of ground-based measurements available from four different stations. The proxies are formulated in terms of sources (concentrations of precursor gases $\left(\mathrm{NO}_{2}\right.$ and $\left.\mathrm{SO}_{2}\right)$ and $\mathrm{UVB}$ radiation intensity near the surface) and a sink term related to removal of the precursor gases due to condensation on pre-existing aerosols. A-Train satellite data are used as input to compute proxies. Both the input data and the resulting proxies are compared with those obtained from ground-based measurements. In particular, a detailed study is presented on the substitution of the local condensation sink (CS) with satellite aerosol optical depth (AOD), which is a columnintegrated parameter. One of the main factors affecting the disagreement between CS and AOD is the presence of elevated aerosol layers. Overall, the correlation between proxies calculated from the in situ data and observed nucleation mode particle number concentrations $\left(N_{\text {nuc }}\right)$ remained low. At the time of the satellite overpass (13:00-14:00 LT) the highest correlation is observed for $\mathrm{SO}_{2} / \mathrm{CS}\left(R^{2}=0.2\right)$. However, when the proxies are calculated using satellite data, only $\mathrm{NO}_{2} /$ AOD showed some correlation with $N_{\text {nuc }}\left(R^{2}=0.2\right)$.
\end{abstract}

This can be explained by the relatively high uncertainties related especially to the satellite $\mathrm{SO}_{2}$ columns and by the positive correlation that is observed between the ground-based $\mathrm{SO}_{2}$ and $\mathrm{NO}_{2}$ concentrations. In fact, results show that the satellite $\mathrm{NO}_{2}$ columns compare better with in situ $\mathrm{SO}_{2}$ concentration than the satellite $\mathrm{SO}_{2}$ column. Despite the high uncertainties related to the proxies calculated using satellite data, the proxies calculated from the in situ data did not better predict $N_{\text {nuc }}$. Hence, overall improvements in the formulation of the proxies are needed.

\section{Introduction}

Aerosol particles are key constituents in the Earthatmosphere system that can alter climate through their direct and indirect effects on the Earth's radiation budget. Aerosols affect the radiation budget directly by scattering and absorbing solar radiation and indirectly by acting as cloud condensation nuclei or ice nuclei and modifying clouds' radiative properties and lifetimes. However, the quantification of the aerosol effects on climate is very complex and large uncertainties still exist due to the high spatial and temporal variability of aerosol mass and particle number concentrations (e.g. IPCC, 2013). Besides the climatic effects, aerosols affect human life by reducing the air quality and visibility as 
well as affecting human health, especially in urban areas. Particulate air pollution has been associated with adverse cardiovascular and pulmonary diseases and even with rises in the numbers of deaths among older people (e.g. Seaton et al., 1995; Utell et al., 2000; Schnelle-Kreis, 2009).

Primary aerosol particles, e.g. sea spray aerosol, desert dust, aerosol generated from biomass burning, and fossil fuel combustion, are emitted directly into the atmosphere. Secondary particles are formed from precursor gases through gas-to-particle conversion. The formation of new particles is strongly connected to the presence of sulphuric acid and other vapours of very low volatility, as well as the magnitude of solar radiation (e.g. Kulmala et al., 2005; Kulmala and Kerminen, 2008). However, pre-existing aerosol particles act as a sink for the vapours, inhibiting new aerosol formation (e.g. Kulmala and Kerminen, 2008). These new nanometresize aerosol particles grow through condensation and coagulation to sizes where they may act as cloud condensation nuclei (particle diameter $D_{\mathrm{p}}>\sim 50 \mathrm{~nm}$ ) or where they are large enough $\left(D_{\mathrm{p}}>\sim 100 \mathrm{~nm}\right)$ to scatter solar radiation and thus affect the Earth's radiation budget.

Several studies have shown that nucleation occurs frequently in the continental boundary layer and free troposphere from clean to polluted environments (Kulmala et al., 2004; Kulmala and Kerminen, 2008, and references therein). Laakso et al. (2008) and Vakkari et al. (2011) have studied new particle formation over moderately polluted savannah ecosystems in South Africa and found that nucleation takes place in the boundary layer almost every sunny day throughout the year with a frequency of as high as $69 \%$ of all analyzed days (Vakkari et al., 2011). Hirsikko et al. (2012) extended the studies in South Africa to a polluted measurement site and found an even higher frequency for the nucleation event days (86\%), which is among the highest event frequencies reported in the literature so far. Hirsikko et al. (2013) also studied the causes for two or three consecutive daytime nucleation events, followed by subsequent particle growth during the same day. They concluded that the multiple events were associated with $\mathrm{SO}_{2}$-rich air from industrial sources.

Satellite instruments have been providing global observations of the Earth's atmosphere for 3 decades (e.g. Lee et al., 2009; Kokhanovsky and de Leeuw, 2009; Burrows et al., 2011). Information about the spatial distribution of aerosols and trace gases can be obtained from multiple instruments with various temporal and spatial resolution and coverage. Passive remote sensing instruments such as NASA's Ozone Monitoring Instrument (OMI) on-board the AURA platform or the Moderate Resolution Imaging Spectroradiometer (MODIS) on-board the Terra and Aqua platforms use solar radiation to detect either trace gases or aerosol and cloud properties. Trace-gas remote sensing techniques using OMI are based on the trace-gas absorption features in the UV region (wavelength $\lambda \sim 200-400 \mathrm{~nm}$ ), whereas the remote sensing of aerosol particles is mainly based on measurements in the UV/visible and near-infrared regions $(\lambda \sim 500$
$2000 \mathrm{~nm}$ ). Since the aerosol measurements utilize only the optically active size range of the solar spectrum, the detectable aerosol sizes are limited to particles with diameters greater than about $100 \mathrm{~nm}$. Nucleation mode particles (smaller than about $25-30 \mathrm{~nm}$ in diameter), therefore, cannot be detected directly using satellite instruments. In 2011, Kulmala et al. introduced proxies, i.e. parameterizations, for estimating the number concentrations of nucleation mode $\left(N_{\text {nuc }}\right)$ simplified for use with satellite data. These simplifications were made assuming that in situ parameters could be replaced with satellite-based observations. Their study was the first attempt to estimate the global nucleation mode aerosol concentrations using data derived from satellite measurements. The proxies were defined in terms of sources and sinks. The nucleation source terms consist of precursor gas column densities $\left(\mathrm{NO}_{2}\right.$ or $\left.\mathrm{SO}_{2}\right)$ and UV-radiation intensity near the surface (all from OMI as opposed to in situ data in the initial proxies) whereas the sink term, i.e. the condensation sink (CS) in the original proxy formulation related to the aerosol surface area concentration, is assumed to be proportional to the aerosol optical depth (AOD, from MODIS). More recently Crippa et al. (2013) formulated a new proxy algorithm for ultrafine particle number concentrations based on satellite-derived parameters. They used a multivariate linear regression approach to derive the proxy, which the source terms consisted of $\mathrm{SO}_{2}$, UV (from OMI), and $\mathrm{NH}_{3}$ (from Tropospheric Emission Spectrometer). The sink term was formulated using MODIS (collection 5.0) AOD and the Ångström exponent, which expresses the spectral dependence of AOD on the wavelength. However, there are issues with the Ångström coefficient (e.g. Mielonen et al., 2011), and thus this parameter is no longer included in the most recent MODIS collection 6.0 land parameters (Levy et al., 2013).

In this work we evaluate the simplifications and underlying assumptions of the method introduced in Kulmala et al. (2011) to estimate the number concentration of nucleation mode particles from satellite-derived data. The study area is the north-eastern part of South Africa $\left(25-28^{\circ} \mathrm{S}, 25.5-\right.$ $30.5^{\circ} \mathrm{E}$, Fig. 1). Even though the area is not very large, it comprises lots of contrasts from the emission point of view: the cities of Johannesburg and Pretoria, as well as highly industrialized areas especially east from the cities, vs. a very clean background in the western part of the study area. The study period considered is January 2007-December 2010. There are also four different measurement stations located within the region of interest, where observations of various in situ parameters were available.

This work comprises of two parts:

1. A detailed investigation of replacing the condensation sink (defined below in Eq. 8), a local parameter evaluated from in situ observations, with the AOD, a columnintegrated aerosol property available from satellite. 
Table 1. A summary of the measurements used in this study. Listed are only those measurements from the study period 1 January $2007-$ 31 December 2010.

\begin{tabular}{|c|c|c|c|}
\hline Instrument & Measurement area/location & Measurement period & Measured parameters \\
\hline $\begin{array}{l}\text { Ozone Monitoring Instrument } \\
\text { (OMI, Aura satellite) }\end{array}$ & $\begin{array}{l}25.0-28.0^{\circ} \mathrm{S}, 25.5-30.5^{\circ} \mathrm{E} \\
\text { (whole study area) }\end{array}$ & $\begin{array}{l}\text { Jan } 2007-\text { Dec } 2010 \text {, } \\
\text { obs. appr. once/day, } \\
\text { only cloud-free obs. }\end{array}$ & $\begin{array}{l}\mathrm{NO}_{2} \text { and } \mathrm{SO}_{2} \text { column den- } \\
\text { sities, UVB irradiance }\end{array}$ \\
\hline $\begin{array}{l}\text { Moderate Imaging Spectro- } \\
\text { radiometer (MODIS, Aqua } \\
\text { satellite) }\end{array}$ & $\begin{array}{l}25.0-28.0^{\circ} \mathrm{S}, 25.5-30.5^{\circ} \mathrm{E} \\
\text { (whole study area) }\end{array}$ & $\begin{array}{l}\text { Jan } 2007-\text { Dec } 2010 \text {, } \\
\text { obs. appr. once/day, } \\
\text { only cloud-free obs. }\end{array}$ & $\begin{array}{l}\text { Column-integrated aerosol } \\
\text { optical depth at } 550 \mathrm{~nm} \\
\text { wavelength }\end{array}$ \\
\hline $\begin{array}{lr}\text { Cloud-Aerosol } & \text { Lidar with } \\
\text { Orthogonal } & \text { Polarization } \\
\text { (CALIOP, } & \text { satellite-based } \\
\text { lidar) } & \end{array}$ & $\begin{array}{l}\text { Selected locations within } \\
\text { the study area }\end{array}$ & $\begin{array}{l}\text { Selected days be- } \\
\text { tween Jan } 2007 \text { and } \\
\text { Dec } 2010\end{array}$ & $\begin{array}{l}\text { Vertical profile of aerosol } \\
\text { extinction at } 532 \mathrm{~nm} \text { wave- } \\
\text { length }\end{array}$ \\
\hline $\begin{array}{l}\text { Aerosol Robotic Network } \\
(\text { AERONET) sunphotometer } \\
\text { (in situ) }\end{array}$ & $\begin{array}{l}\text { Elandsfontein } \\
\left(26.25^{\circ} \mathrm{S}, 29.42^{\circ} \mathrm{E}\right)\end{array}$ & $\begin{array}{l}\text { Mar-Dec 2010, only } \\
\text { cloud-free obs. during } \\
\text { daylight. }\end{array}$ & $\begin{array}{l}\text { Column-integrated aerosol } \\
\text { optical depth at } 500 \mathrm{~nm} \\
\text { wavelength. }\end{array}$ \\
\hline Nephelometer (in situ) & Elandsfontein & Mar-Dec 2010 & $\begin{array}{l}\text { Aerosol scattering coeffi- } \\
\text { cient }\end{array}$ \\
\hline $\begin{array}{l}\text { Differential mobility particle } \\
\text { sizer (DMPS, in situ) }\end{array}$ & $\begin{array}{l}\text { Marikana } \quad\left(25.70^{\circ} \mathrm{S} \text {, }\right. \\
\left.27.48^{\circ} \mathrm{E}\right) \\
\text { Botsalano } \\
\left(25.54^{\circ} \mathrm{S}, 25.75^{\circ} \mathrm{E}\right) \\
\text { Welgegund } \\
\left(26.57^{\circ} \mathrm{S}, 26.94^{\circ} \mathrm{E}\right)\end{array}$ & $\begin{array}{l}\text { Marikana: Feb 2008- } \\
\text { May } 2010 \\
\text { Botsalano: Jan 2007- } \\
\text { Feb } 2008 \\
\text { Welgegund: } \\
\text { Dec } 2010\end{array}$ & $\begin{array}{l}\text { Particle size distribution, } \\
\text { condensation sink, event } \\
\text { classification }\end{array}$ \\
\hline \multirow[t]{2}{*}{$\begin{array}{l}\text { Scanning mobility particle } \\
\text { sizer (SMPS, in situ) }\end{array}$} & Elandsfontein & Mar-Dec 2010 & $\begin{array}{l}\text { Particle size distribution, } \\
\text { condensation sink }\end{array}$ \\
\hline & All in situ stations & dates/station as above & $\begin{array}{l}\mathrm{NO}_{x} \text { and } \mathrm{NO}, \mathrm{SO}_{2} \text { global } \\
\text { radiation, } T, \mathrm{RH}\end{array}$ \\
\hline
\end{tabular}
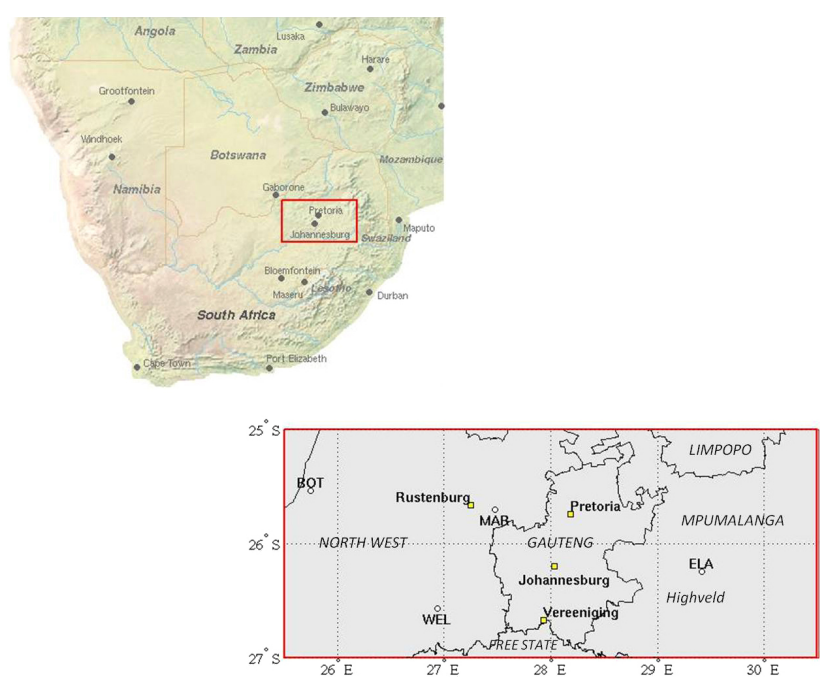

Figure 1. The study area and locations of the in situ measurement stations $; \mathrm{BOT}=$ Botsalano, MAR $=$ Marikana, WEL $=$ Welgegund, and ELA = Elandsfontein.
2. The estimation of how well satellite data can be used to compute proxies for nucleation mode particle number concentrations. This comprises the analysis of both the satellite- and in-situ-based proxy components and the proxies, as well as the comparison of the proxies with the measured concentration of nucleation mode particles. The influence of the uncertainties in the satellitederived quantities on the proxy is also evaluated.

\section{Data}

In this study, a variety of data was used from satellite instruments and ground-based stations (see Table 1 for a summary). Satellite data used originate from NASA's AfternoonTrain (A-Train) constellation. The A-Train constellation consists of seven satellites that are on a same polar-orbiting track and follow each other closely, enabling near-simultaneous observations of a variety of atmospheric parameters. The equatorial overpass for the A-Train satellites is around 1:30 p.m. local time. In this study we use OMI Level 2 products, i.e. the $\mathrm{NO}_{2}$ tropospheric column (Bucsela et al., 2013), 
the $\mathrm{SO}_{2}$ planetary boundary layer (PBL) product (Krotkov et al., 2006, 2008), and the $310 \mathrm{~nm}$ irradiance (UVB) at the surface at local noon (Tanskanen et al., 2006). It is noted that the $\mathrm{OMI} \mathrm{SO}_{2}$ PBL product describes the $\mathrm{SO}_{2}$ concentration integrated over the whole atmospheric column, and PBL refers to the a priori profile assumed in the retrieval of this product. The OMI L2 products are provided with a nominal spatial resolution of $13 \times 24 \mathrm{~km}^{2}$. For the current study they were re-gridded onto a $3 \mathrm{~km} \times 3 \mathrm{~km}$ geographical grid as in Fioletov et al. (2011). In this way the effective spatial resolution could be increased despite the instrument resolution being coarser than the grid. For $\mathrm{NO}_{2}$ and $\mathrm{SO}_{2}$, only those observations where the (radiative) cloud fraction was below $20 \%$ were used.

According to Lamsal et al. (2014), and references therein, the uncertainty in the OMI $\mathrm{NO}_{2}$ tropospheric column concentrations is about $0.75 \times 10^{15}$ molec $\mathrm{cm}^{-2}$, whereas Krotkov et al. (2008) report that the $\mathrm{SO}_{2}$ PBL product could be associated with noise as high as $1.5 \mathrm{DU}$. However, averaging the $\mathrm{SO}_{2}$ columns over longer a period and/or over a larger spatial area could reduce the noise to $0.3-0.6 \mathrm{DU}$. For OMI UVB irradiance the relative uncertainty is on average $7 \%$ but could be higher, e.g. due to some episodic aerosol plumes (Tanskanen et al., 2006).

The AOD used in this study is the MODIS Aqua collection 6.0 AOD product at $3 \mathrm{~km}$ spatial resolution (Levy et al., 2013). The relative uncertainty for the MODIS AOD over land is reported as $0.05+15 \%$. For selected cases, vertical aerosol extinction profiles from the Cloud-Aerosol Lidar and Infrared Pathfinder Satellite Observation (CALIPSO) (Winker et al., 2007) are also used.

The in situ data used in this study are collected at four different stations in South Africa: Elandsfontein (ELA), Marikana (MAR), Botsalano (BOT), and Welgegund (WEL). All of these stations are located in the north-eastern part of the country shown in Fig. 1. Depending on the station, the measured parameters included e.g. particle size distribution, extinction coefficient, and trace-gas concentrations. More detailed description of the in situ measurements at the Marikana station can be found e.g. in Venter et al. (2012), at the Welgegund station in Beukes et al. (2013), at the Elandsfontein station in Laakso et al. (2012), and at the Botsalano station in Vakkari et al. (2013). Also data from the Aerosol Robotic Network (AERONET, http://aeronet.gsfc.nasa.gov, Holben et al., 1998) at the Elandsfontein station are used. AERONET is a global ground-based sunphotometer network, providing observations of aerosol optical, microphysical, and radiative properties that are available in a public domain. The aerosol optical properties in the total atmospheric column are derived from the direct and diffuse solar radiation measured by the Cimel sunphotometers.

\section{Proxies}

Kulmala et al. (2011) derived the $N_{\text {nuc }}$ proxies for regionalscale nucleation and nucleation from primary emissions. The proxies were determined as the ratio of a source and a sink term. Regional-scale nucleation is associated with photochemistry and typically occurs over a spatial scale of hundreds of kilometres, whereas nucleation from primary emissions occur in the vicinity of local sources such as industrial or urban areas (Kulmala et al., 2011, and references therein). On a regional scale it was assumed that sulphuric acid acts as the driver of the regional nucleation process. Sulphuric acid is formed by oxidation of sulphur dioxide $\left(\mathrm{SO}_{2}\right)$ with the hydroxyl radical $(\mathrm{OH})$, which, however, is mainly formed via photolysis of ozone and UV radiation. The main sink for sulphur acid is collisions with pre-existing aerosols. Petäjä et al. (2009) derived the proxy for the ambient sulphuric acid as $\mathrm{UV} \cdot\left[\mathrm{SO}_{2}\right] / \mathrm{CS}$, which was considered as the source term in the regional-scale nucleation proxy. Taking into account that in addition to sulphuric acid, the pre-existing aerosols are also the sink for the newly formed particles $\left(N_{\text {nuc }}\right)$, the regional-scale nucleation proxy is determined as (Kulmala et al., 2011)

$P_{N_{\text {nuc }, \text { regional }}}=\frac{\mathrm{UV} \cdot\left[\mathrm{SO}_{2}\right]}{\mathrm{CS}^{2}}$,

where CS denotes the condensation sink of pre-existing aerosols.

Nucleation from primary emissions can be an extremely rapid process. The source term of the corresponding proxy is related to the concentration of nitrogen dioxide $\left(\mathrm{NO}_{2}\right)$ or sulphur dioxide while the sink term is determined by the condensation sink. For nucleation from primary emissions, two proxies are defined as (Kulmala et al., 2011)

$$
\begin{aligned}
& P_{N_{\text {nuc, prim. }}}=\frac{\left[\mathrm{NO}_{2}\right]}{\mathrm{CS}}, \\
& P_{N_{\text {nuc, prim. }}}=\frac{\left[\mathrm{SO}_{2}\right]}{\mathrm{CS}} .
\end{aligned}
$$

In each of the proxies the source terms are estimated from the satellite measurements by replacing the $\mathrm{SO}_{2}$ and $\mathrm{NO}_{2}$ concentrations at the surface with the column densities from the satellite. The amount of global UV radiation is also available from satellite measurements e.g. as a local noon irradiance at $310 \mathrm{~nm}$ wavelength (UVB radiation) at the surface. For the sink parameter (CS), Kulmala et al. (2011) proposed to use the AOD, which describes the total aerosol extinction in the atmospheric column. The relation between the CS and the AOD will be discussed in the following section. By replacing CS with AOD the simplified proxy for using satellite data for primary nucleation becomes

$P_{N_{\text {nuc }}}^{\text {Sat. }}=\frac{\left[\mathrm{NO}_{2}\right]_{\text {column }}}{\mathrm{AOD}}$, 
$P_{N_{\text {nuc. }}}^{\text {Sat. }}=\frac{\left[\mathrm{SO}_{2}\right]_{\text {column }}}{\mathrm{AOD}}$.

For regional nucleation the proxy expressed in terms of satellite data becomes

$P_{N_{\text {nuc. }}}^{\text {Sat. }}=\frac{\mathrm{UV}\left[\mathrm{SO}_{2}\right]_{\text {column }}}{\mathrm{AOD}^{2}}$.

In addition we also considered

$P_{N_{\text {nuc. }}}^{\text {Sat. }}=\frac{\mathrm{UV}}{\mathrm{AOD}^{2}}$

as a potential proxy for the number concentration of nucleation mode particles. This proxy corresponds to the case shown in Kulmala et al. (2011), where the sulphur dioxide concentration was assumed to be constant. In this work the proxy defined in Eq. (7) is considered mainly to study how large effect the satellite-based $\mathrm{SO}_{2}$ has on the performance of the regional-scale nucleation proxy.

\section{Condensation sink and aerosol extinction}

As indicated in the previous section, Kulmala et al. (2011) proposed AOD as a substitute for CS. Both parameters are also roughly proportional to the aerosol surface area distribution. According to e.g. Lehtinen et al. (2003) the condensation sink is defined as

$\mathrm{CS}=2 \pi \rho_{\text {diff }} \int_{0}^{\infty} D_{\mathrm{p}} \beta_{\mathrm{M}}\left(D_{\mathrm{p}}\right) n\left(D_{\mathrm{p}}\right) \mathrm{d} D_{\mathrm{p}}$,

where $D_{\mathrm{p}}$ is the particle radius, $n\left(D_{\mathrm{p}}\right)$ is the particle number size distribution function, $\rho_{\text {diff }}$ is the diffusion coefficient of the condensing vapour, and $\beta_{\mathrm{M}}\left(D_{\mathrm{p}}\right)$ is the transitional correction factor for mass flux (Fuchs and Sutugin, 1971).

Aerosol optical depth describes quantitatively the columnintegrated extinction of solar light caused by atmospheric aerosols and is one of the standard aerosol parameters retrieved from the satellite radiance observations. At a height $z$ and for a wavelength $\lambda$ the aerosol extinction is defined as

$\sigma_{\text {ext }, z, \lambda}=\frac{1}{4} \pi \int_{0}^{\infty} Q_{\text {ext }}\left(\lambda, D_{\mathrm{p}}, m\right) D_{\mathrm{p}}^{2} n\left(D_{\mathrm{p}}\right) \mathrm{d} D_{\mathrm{p}}$,

where $Q_{\text {ext }}$ is the extinction efficiency describing aerosols' ability to scatter and absorb solar light. At a fixed wavelength the extinction efficiency is a complex function of aerosol size and complex refractive index $m$ (which in turn depends on the aerosol particle composition). The particle shape also affects somewhat $Q_{\text {ext }}$, but this is not considered in this study. If the particles are assumed to be spherical, $Q_{\text {ext }}$ can be calculated using a computer code based on the Lorenz-Mie theory (Mishchenko et al., 2002). AOD is obtained by integrating $\sigma_{\text {ext }}$ over the total atmospheric column.
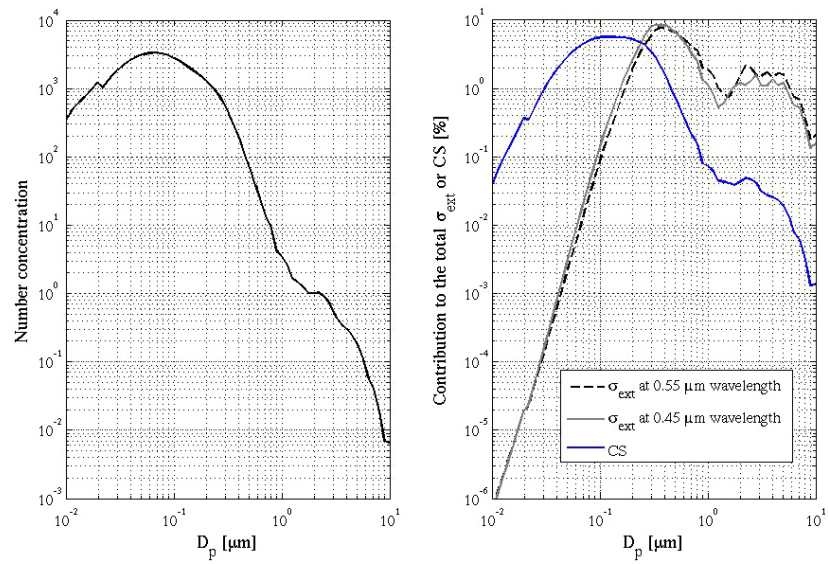

Figure 2. The sensitivity of CS and aerosol extinction coefficient to different particle sizes. In the left panel, the aerosol size distribution that is used to calculate CS and $\sigma_{\text {ext }}$ is calculated for two wavelengths $(0.55$ and $0.45 \mu \mathrm{m})$ assuming spherical particles with a refractive index of $m=1.48+0.001 i$. In the right panel the contribution of each particle size to the total CS and $\sigma_{\text {ext }}$ is shown. The $\sigma_{\text {ext }}$ is calculated for two wavelengths $(0.55$ and $0.45 \mu \mathrm{m})$ assuming spherical particles with a refractive index of $m=1.48+0.001 i$

The differences between CS and $\sigma_{\text {ext }}$ (at a certain height) as a function of particle size are illustrated in Fig. 2. Both parameters are derived using the same aerosol size distribution (Fig. 2, left panel). The $\sigma_{\text {ext }}$ is calculated using a refractive index of $m=1.48+0.003 i$ and wavelengths of 0.55 and $0.45 \mu \mathrm{m}$. As Fig. 2 shows, particles with $D_{\mathrm{p}}$ about 0.05 $0.1 \mu \mathrm{m}$ have the largest contribution to CS, whereas for $\sigma_{\mathrm{ext}}$ the largest contribution is coming from particles with $D_{\mathrm{p}}$ about $0.2-0.8 \mu \mathrm{m}$. The notable difference between the two quantities is that particles $D_{\mathrm{p}}<0.1 \mu \mathrm{m}$ can have a contribution to CS which is several orders of magnitude larger than that to $\sigma_{\text {ext }}$. However, $\sigma_{\text {ext }}$ is significantly more sensitive to particles with $D_{\mathrm{p}}>1.0 \mu \mathrm{m}$ than CS. It is clear that a large change in number concentration of the smaller particle sizes would change the value of total CS when integrated over the size distribution but would have a minor effect on the value of $\sigma_{\text {ext }}$, and vice versa; if e.g. the number concentration of large particles increased, there would be little effect on CS. It is noted that in addition to the theoretical differences the possibility of elevated aerosol layers could affect the columnintegrated values of $\sigma_{\text {ext }}$, i.e. the AOD, which must be considered when comparing the satellite-based AOD with in situ CS.

The response of $\sigma_{\text {ext }}$ to changes in the particle size distribution depends to a certain extent on the particle composition and the measurement wavelength. If the particle absorption is high (i.e. the imaginary part of $m \sim 0.1 i$ ), the contribution of particles $D_{\mathrm{p}}<0.1 \mu \mathrm{m}$ to $\sigma_{\text {ext }}$ would be somewhat higher than in Fig. 2. Shorter wavelengths increase the sensitivity to smaller particles, but as Fig. 2 illustrates, a $0.1 \mu \mathrm{m}$ decrease in wavelength does not improve the sensitivity significantly. 

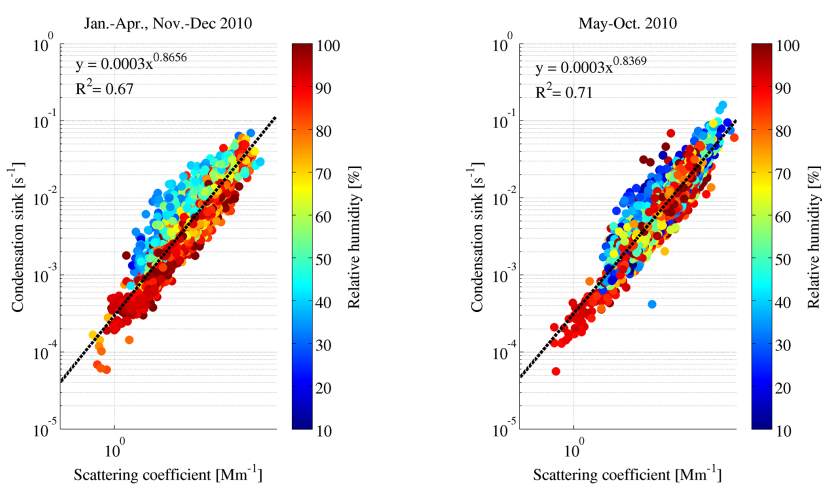

Figure 3. Comparison between condensation sinks derived from particle size distributions, as described in the text, and nephelometer scattering coefficients measured at Elandsfontein station in 2010 for the warm (January-April, November-December) and cold (MayOctober) seasons. CS has been corrected to the ambient relative humidity but the scattering coefficient was measured from dry particles. The data are colour-coded according to ambient relative humidity, of which the strong influence on the relation between CS and scattering coefficient is evident.
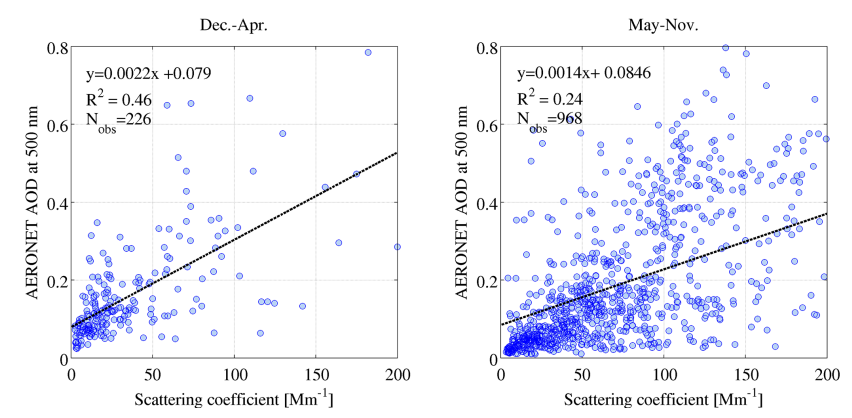

Figure 4. Comparison between $\mathrm{AOD}$ at $500 \mathrm{~nm}$ available from AERONET (see text) and in situ scattering coefficients measured at the Elandsfontein station. The AOD is the column-integrated value of aerosol extinction (scattering + absorption) obtained from sunphotometer measurements. The in situ scattering coefficient is measured with a nephelometer.

Much shorter wavelengths would be needed to increase the sensitivity of $\sigma_{\text {ext }}$ to particles $D_{\mathrm{p}}<0.1 \mu \mathrm{m}$, but such measurements could not be carried out in a real atmosphere.

\section{Results}

The proxies as defined in Sect. 3 are formulated in terms of parameters which are either obtained from ground-based in situ measurements (Eqs. 1-3) or from satellite data (Eqs. 47). In this section the performance of these proxies is critically evaluated and in particular each of the satellite-based parameters is critically examined.
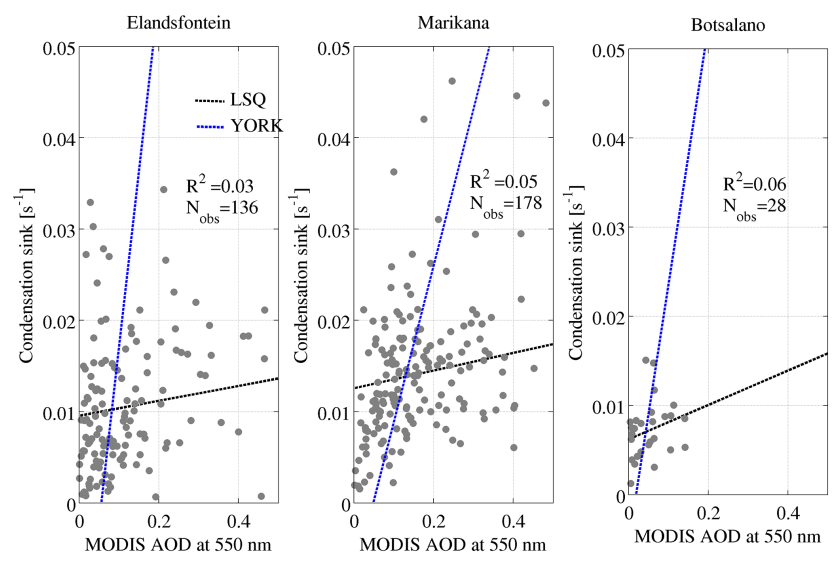

Figure 5. Comparison between MODIS AOD and in situ CS. The MODIS AOD values are spatial averages calculated from the observations within $3 \mathrm{~km}$ distance from the measurement station, whereas the CS values are $1 \mathrm{~h}$ averages (13:00-14:00 LT). The black lines represent the slope from least squares linear fitting (LSQ). The blue lines represent the fitting method where the uncertainties related to CS and AOD values have been taken into account (YORK; York et al., 2004). The uncertainty for CS was set to $10 \%$ and for AOD to $0.05+15 \%$ (Levy et al., 2013).

\subsection{Comparison of condensation sink and aerosol optical depth}

Replacing CS with AOD is perhaps the most crucial assumption when determining the proxies using satellite data, as indicated in Kulmala et al. (2011). Apart from the sensitivity of these parameters for different particle sizes discussed in Sect. 3.1, other differences play a role, such as the vertical variation of the aerosol concentrations, the particle size range considered, and the dependence of aerosol particle size on relative humidity. CS is determined from measured dry particle size distributions with a correction for ambient humidity. CS at Botsalano and Marikana has been estimated from submicron size distribution while at Elandsfontein size distributions up to $10 \mu \mathrm{m}$ were used. In contrast, the AOD is an integrated quantity with contributions from all optically active aerosols throughout the whole atmospheric column. To assess the effect of these different factors on the relation between the AOD and CS, the following comparisons are made:

- in situ CS with nephelometer aerosol scattering coefficient

- in situ nephelometer aerosol scattering coefficient with AOD from AERONET

- in situ CS with AOD from both AERONET and satellite measurements.

Coincident measurements of size distributions to derive the CS and aerosol scattering coefficients from a nephelometer are only available from the Elandsfontein measurement station. The comparison between CS and scattering coefficient 
serves to eliminate effects of the vertical variation of the aerosol concentrations on the comparison. The nephelometer measures the dry particle scattering at $0.525 \mu \mathrm{m}$ wavelength and the results are presented at standard temperature and pressure for the atmosphere. The maximum particle size is limited to $D_{\mathrm{p}} \sim 10 \mu \mathrm{m}$. It is noted that the nephelometer considers only aerosol scattering and not the total extinction, which would also require information on absorption. However, the contribution of absorption to the total aerosol extinction is generally much smaller than scattering. Laakso et al. (2012) reported that at Elandsfontein the absorption was increased during the coldest months (May-October) due to biomass burning (domestic burning of coal for heating and cooking) contributing about $15-20 \%$ to the total aerosol extinction, whereas during the warmer months (NovemberApril) absorption contributed $\sim 10 \%$ of the total aerosol extinction. To take the seasonal variation of absorption into account, the CS and the scattering coefficients were compared separately for the periods May-October and NovemberApril. The results in Fig. 3 show that, for both periods, scattering coefficients and CS were well correlated with $R^{2}=$ 0.67 for November-April and $R^{2}=0.71$ for May-October. The $R^{2}$ values were somewhat higher than those from measurements at a clean continental boreal forest measurement site in Hyytiälä, southern Finland $\left(R^{2}=0.62\right.$, Virkkula et al., 2011).

The next step is to compare the nephelometer scattering coefficient to the AOD to evaluate effects of the possible occurrence of elevated aerosol layers and/or boundary layer mixing. Also the presence of large dust particles might have some effect on the comparison due to the limited particle size in the nephelometer inlet. In this comparison we first compare with AERONET measurements of AOD at Elandsfontein, which are more accurate than those retrieved from satellite data. As Fig. 4 shows, the correlations between the AERONET AOD and the in situ scattering coefficient (warm season $R^{2}=0.46$, cold season $R^{2}=0.24$ ) are lower than those between the CS and the scattering coefficient. This indicates that the elevated aerosol layers and boundary layer mixing might affect more than the theoretical differences when estimating the sink of pre-existing aerosols by using the AOD.

For the comparison of CS with the AOD retrieved from MODIS, daily AOD values were used which are spatial averages of the observations within a $3 \mathrm{~km}$ radius from each measurement station. As Fig. 5 shows, the CS vs. satellite AOD data are scattered all over the graph and although there is a tendency of increasing CS with increasing AOD there is no apparent correlation $\left(0.03 \leq R^{2} \leq 0.06\right)$. As an alternative, a bivariate method (York et al., 2004) was applied to account for the uncertainties associated with both CSs and MODIS AODs in the fitting. For CS the uncertainty was assumed to be $10 \%$ (Petäjä et al., 2013) and for MODIS AOD an uncertainty of $0.05+15 \%$ was used (Levy et al., 2013). This means that for low AOD the relative uncertainty is rather

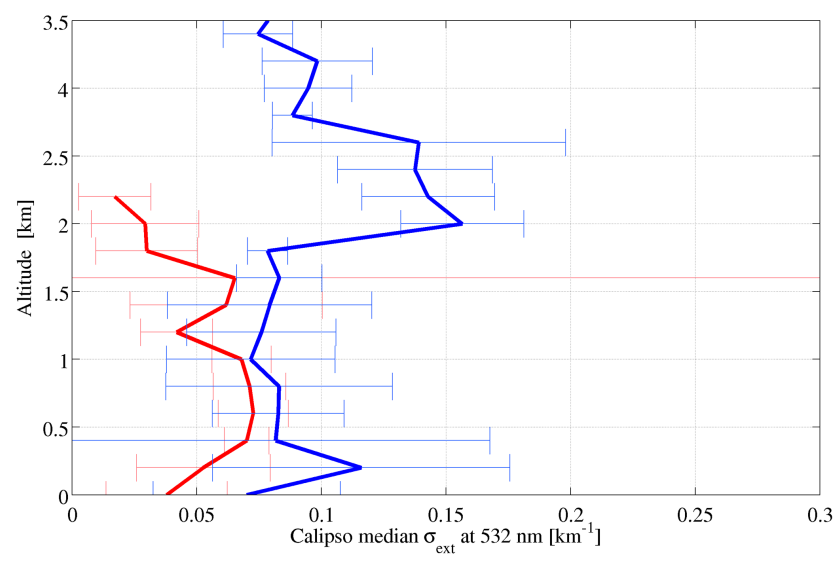

Figure 6. Median CALIPSO extinction profiles for days when MODIS AOD $>0.15$ (blue) and AOD $\leq 0.15$ (red). The CALIPSO profiles are collected within $50 \mathrm{~km}$ radius from the Marikana station. The horizontal bars represent the interquartile ranges. The median extinction profile for MODIS AOD $\leq 0.15$ cases extends only up to $2.2 \mathrm{~km}$ because the quality of the data above $2.2 \mathrm{~km}$ was too low.

high; e.g. for $\mathrm{AOD}=0.1$ the relative uncertainty would be $65 \%$. As Fig. 5, shows the bivariate method gave very different results than least squares linear fitting.

At Marikana and Elandsfontein the largest observed AODs are not related to largest CS, which could be due to the presence of elevated aerosol layers. In a recent study by Giannakaki et al. (2015) data from a ground-based lidar at Elandsfontein are analyzed and the results show that the mean contribution of elevated aerosol layers to the AOD is $46 \%$. To estimate the effect of elevated aerosol layers on the CS-AOD comparison at Marikana, CALIPSO observations of aerosol vertical extinction profiles are used. All CALIPSO daytime overpasses between 8 February 2008 and 17 May 2010 within $50 \mathrm{~km}$ from the Marikana station were considered. Due to the small CALIPSO swath width only 48 days of data are available. At Marikana the median MODIS AOD is 0.15 for the whole measurement period and, as Fig. 5 shows, the CS values are less scattered when AODs are smaller than the median. Therefore the vertical aerosol extinction profiles from CALIPSO are studied separately for the cases where MODIS AOD $\leq 0.15$ and AOD $>0.15$. As Fig. 6 shows, for higher AODs the median extinction profile indicates an elevated aerosol layer, which supports the result that high AODs also at Marikana are likely to be associated with an elevated aerosol layer.

\subsection{Proxies defined from the in situ data and comparison with $N_{\text {nuc }}$}

The proxies are first computed using in situ measurements from Marikana and Elandsfontein following Eqs. (1)-(3) to evaluate how well each of them could predict the nucleation mode number concentration within our study area. It is noted 
a)

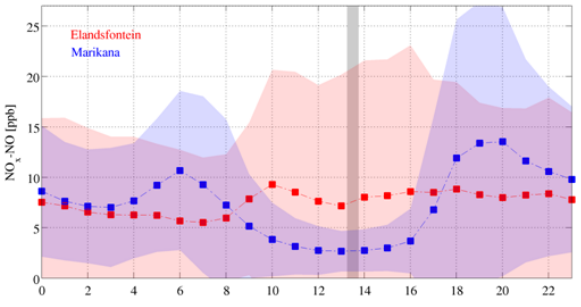

c)

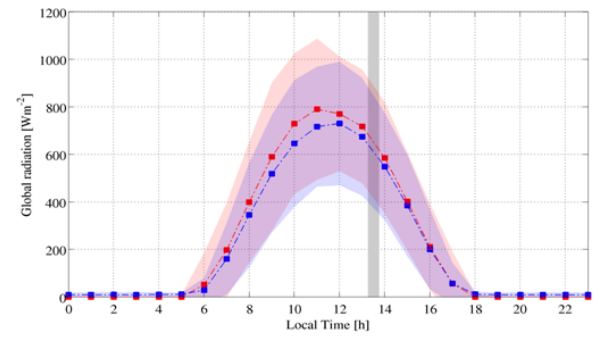

b)

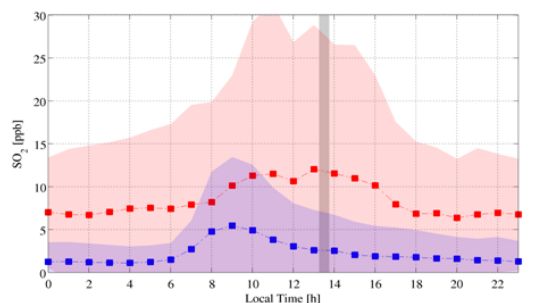

d)

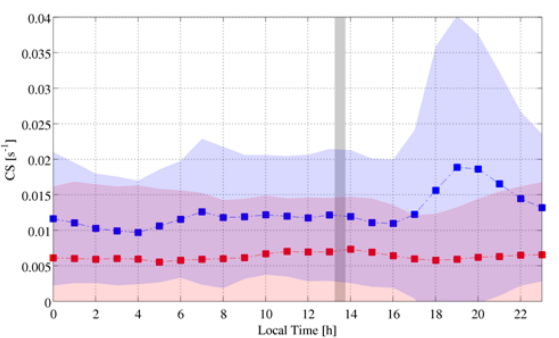

e)

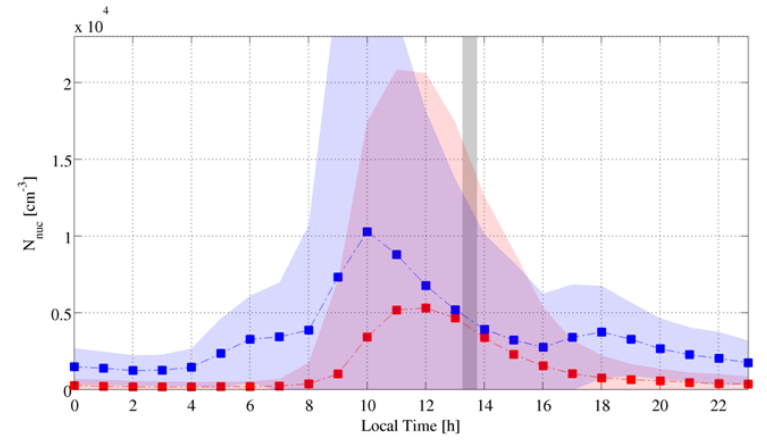

Figure 7. Diurnal variation of (a) $\mathrm{NO}_{x}-\mathrm{NO}$, (b) $\mathrm{SO}_{2}$, (c) global radiation, (d) CS, and (e) $N_{\text {nuc }}$ at Elandsfontein (red) and Marikana (blue) stations. The grey columns represent the time window for the satellite overpass. The blue and red shading denote the 75th and 25th percentiles. It is noted that CS at Elandsfontein is defined with particles $D_{\mathrm{p}}<10 \mu \mathrm{m}$ and at Marikana with particles $D_{\mathrm{p}}<1 \mu \mathrm{m}$. $N_{\text {nuc }}$ at Marikana represents particles $D_{\mathrm{p}}<30 \mathrm{~nm}$ while at Elandsfontein $N_{\text {nuc }}$ represents particles $D_{\mathrm{p}} 10-30 \mathrm{~nm}$.

that due to different instrumentation, $N_{\text {nuc }}$ from Marikana consists of particles with $D_{\mathrm{p}}<30 \mathrm{~nm}$, but at Elandsfontein $N_{\text {nuc }}$ consists of particles with $D_{\mathrm{p}} 10-30 \mathrm{~nm}$. In addition, CS at Marikana is defined from submicron particles whereas at Elandfontein CS is defined from particles with $D_{\mathrm{p}}<10 \mu \mathrm{m}$.

Figure 7 shows the diurnal variation of each of the in situ proxy components and the number concentration of nucleation mode particles. At Marikana the $N_{\text {nuc }}$ median peaks about 10 a.m. and at Elandsfontein about $1 \mathrm{~h}$ later. At the time of the satellite overpass the median of $N_{\text {nuc }}$ is lower than before noon at both locations and about the same order of magnitude. The diurnal variation of $\mathrm{NO}_{x}-\mathrm{NO}$ and $\mathrm{SO}_{2}$ concentrations shows somewhat different characteristics at Marikana than at Elandsfontein. The morning and evening peaks of $\mathrm{NO}_{x}$-NO at Marikana are most likely associated with household combustion and traffic, whereas the single $\mathrm{SO}_{2}$ peak in the morning is most likely related to the industrial emissions and the break-up of the inversion layers that form quite regularly in the South African Highveld (Venter et al., 2012). At Elandsfontein, where the major emission source is heavy in- dustry, an increase in the $\mathrm{NO}_{x}-\mathrm{NO}$ and the $\mathrm{SO}_{2}$ concentration medians is seen at about 10 a.m. The median of $\mathrm{SO}_{2}$ concentration decreases in the late afternoon while the median of $\mathrm{NO}_{x}-\mathrm{NO}$ concentration does not vary much. At the time of the satellite overpass the $\mathrm{NO}_{x}-\mathrm{NO}$ and $\mathrm{SO}_{2}$ medians are much higher at Elandsfontein than at Marikana. Results show also that at the time of the satellite overpass $\mathrm{NO}_{x}-\mathrm{NO}$ and $\mathrm{SO}_{2}$ are positively correlated: at Elandsfontein $R^{2}=0.58$ and at Marikana $R^{2}=0.32$. At Elandsfontein CS does not show any clear diurnal variation and it is systematically lower than at Marikana. Also at Marikana the diurnal variation of the CS is rather weak during the daytime but a peak in the median is seen in the evening.

Figure 8 shows the diurnal variation of the in situ proxies at Marikana and Elandsfontein. The comparison of the diurnal variation of the proxies and $N_{\text {nuc }}$ indicates that the proxy- $N_{\text {nuc }}$ relation depends on the time of the day. At the time of the satellite overpass (13:00-14:00 LT) the highest correlation with $N_{\text {nuc }}$ at Marikana is obtained with the $\mathrm{SO}_{2} / \mathrm{CS}$-proxy $\left(R^{2}=0.22\right.$, Fig. 9), but at Elandsfontein the 
a)

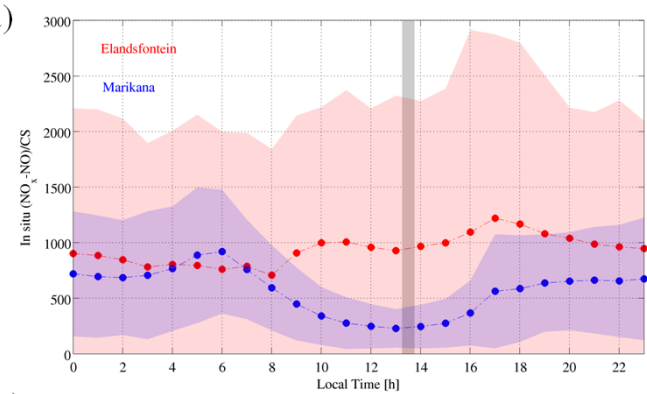

c)

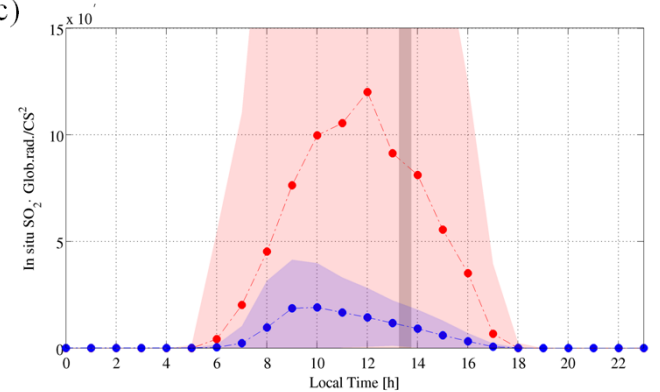

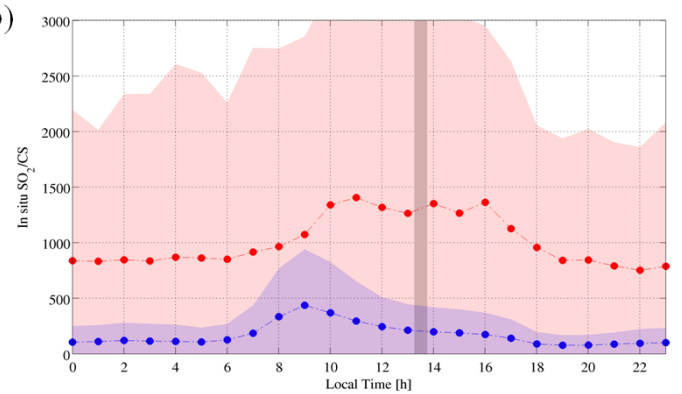

d)

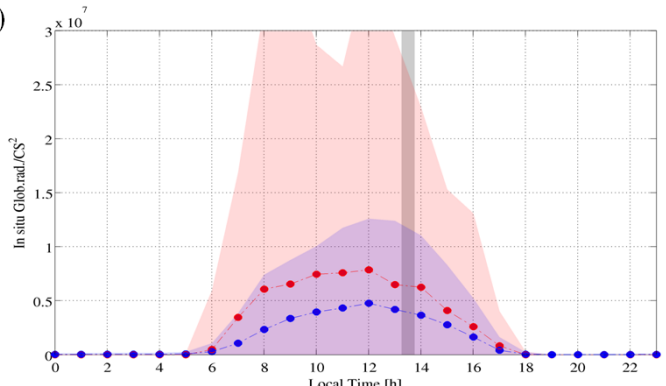

Figure 8. Diurnal variation of the proxies calculated using in situ data at Elandsfontein (red) and at Marikana (blue) stations. The red and blue shaded areas denote the 75th and 25th percentile ranges. The grey column represents the time of the satellite overpass.

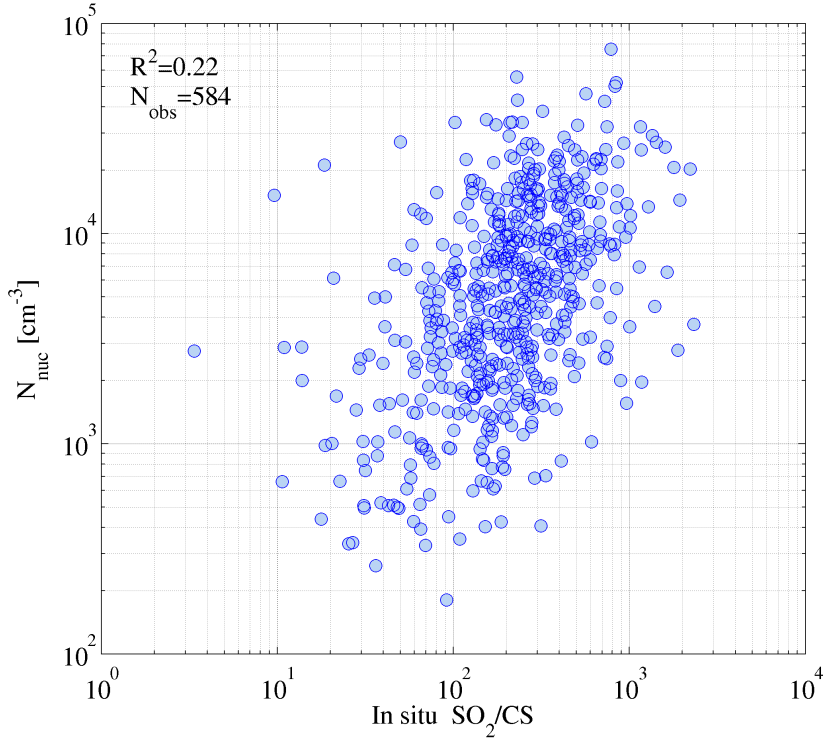

Figure 9. Correlation between nucleation mode number concentration and $\mathrm{SO}_{2} / \mathrm{CS}$ proxy calculated using in situ data at Marikana measurement station at the time of the satellite overpass (13:00 14:00 LT).

correlation remains below 0.1. At Marikana the correlation of $N_{\text {nuc }}$ with $\mathrm{SO}_{2} \cdot \mathrm{UV} / \mathrm{CS}^{2}$ proxy (Eq. 1) is not as good at the time of the satellite overpass, but at 9-10 a.m. $R^{2}=0.25$. The $\left(\mathrm{NO}_{x}-\mathrm{NO}\right) / \mathrm{CS}$ and UV/CS ${ }^{2}$ proxies do not perform well in predicting $N_{\text {nuc }}$. Also, it is noted that at the time of the satellite overpass all the proxy values show much higher me- a)

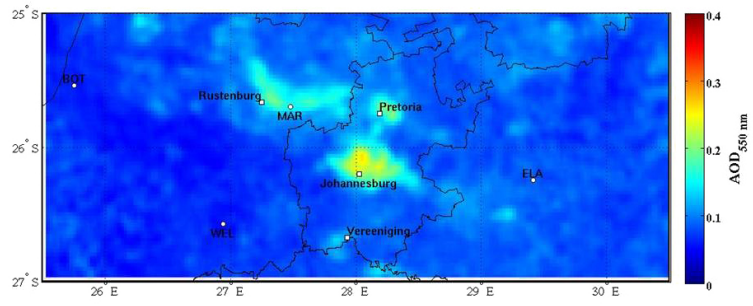

b)

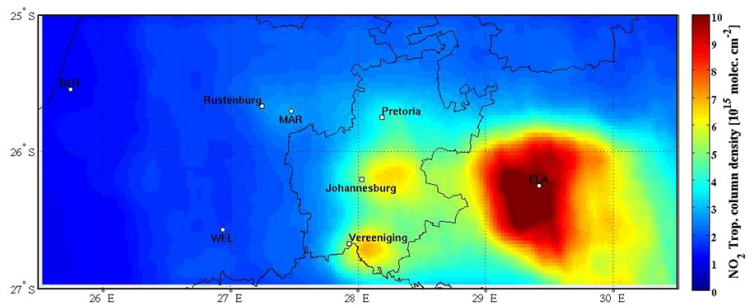

c)

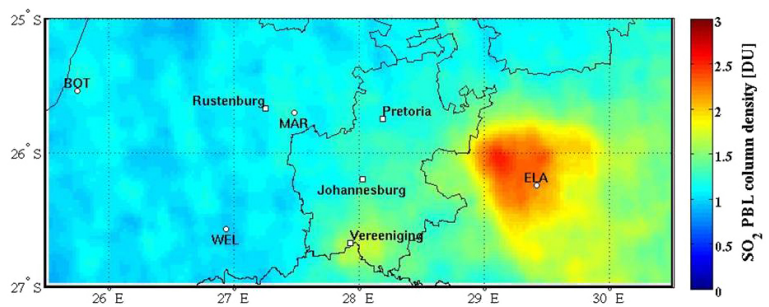

Figure 10. MODIS AOD (a), OMI $\mathrm{NO}_{2}$ (b), and $\mathrm{SO}_{2}$ (c) column density medians for a 4-year period from January 2007 to December 2010. The locations of the in situ measurement stations $(\mathrm{ELA}=$ Elandsfontein, $\mathrm{MAR}=$ Marikana, $\mathrm{BOT}=$ Botsalano, and $\mathrm{WEL}=$ Welgegund) are marked with white dots. 

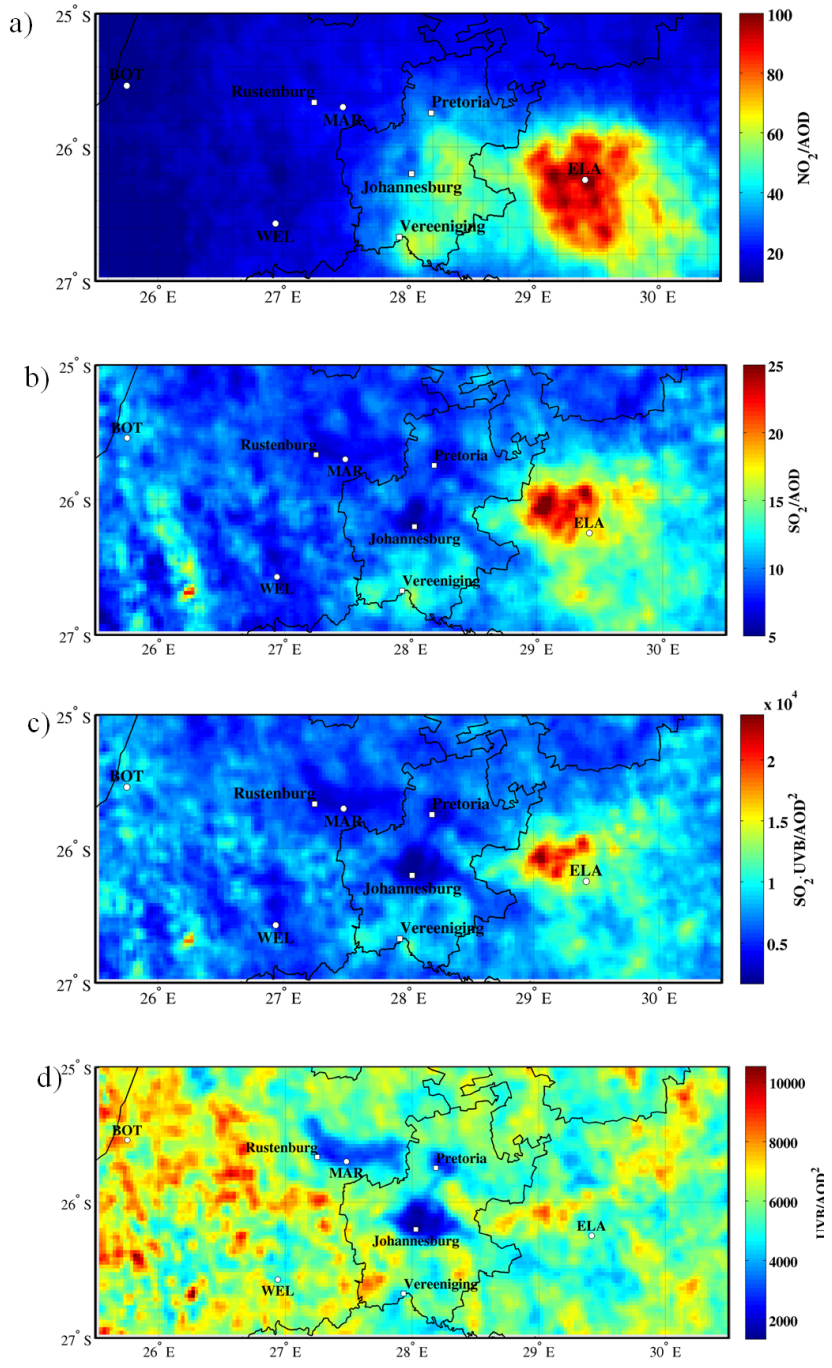

Figure 11. Spatial pattern of proxy medians for 2007-2010 calculated using satellite data. The proxies are (a) $\mathrm{NO}_{2} / \mathrm{AOD}$, (b) $\mathrm{SO}_{2} / \mathrm{AOD}$, (c) $\mathrm{SO}_{2} \cdot \mathrm{UVB} / \mathrm{AOD}^{2}$, and (d) $\mathrm{UVB}_{\mathrm{AOOD}}{ }^{2}$.

dian values at Elandsfontein than at Marikana while the median for $N_{\text {nuc }}$ is about the same at both locations. At Elandsfontein somewhat better correlations with $N_{\text {nuc }}$ are observed when only the source terms of the proxies are considered. For example, the values of $R^{2}$ between $N_{\text {nuc }}$ and SO.UV are 0.35 at 10:00-11:00 LT and 0.14 at 13:00-14:00 LT, but when the sink-term $\mathrm{CS}^{2}$ is included in the proxy there is no correlation. At Marikana CS does not have as high an influence on the proxy performance as at Elandsfontein.

This differs from the results reported for southern Finland (Kulmala et al., 2011) in that $\mathrm{SO}_{2}$ in our study has a strong effect on the performance of the proxy: without $\mathrm{SO}_{2}$ the UV/CS ${ }^{2}$ term does not correlate with $N_{\text {nuc }}$. Given that the satellite data are associated with much higher uncertainties than the in situ measurements, these in-situ-based results can be considered as upper limit for the overall performance of the proxies computed using satellite data (Eqs. 4-7).

\subsection{Proxies using satellite data}

\subsubsection{Spatial pattern of the satellite-based proxies}

Each of the satellite-based parameters is analyzed from January 2007 to December 2010. Figure 11 shows the 4-year medians of $\mathrm{SO}_{2}$ and $\mathrm{NO}_{2}$ column densities obtained from the OMI instrument as well as the AOD at $550 \mathrm{~nm}$ from MODIS Aqua observations. Daily satellite data are used to define the satellite-based proxies over the study area (Eqs. 47). Figure 12 shows the 4 -year median spatial patterns for the four satellite-based proxies. The spatial patterns of these four proxies are quite different and in particular there is a large difference between the spatial variation of the regional proxies and that of the proxies for nucleation from primary emissions. As expected, the latter strongly reflects the spatial distributions of the precursor gases with high concentrations over the Highveld industrial area, where the values of $\mathrm{NO}_{2}$ and $\mathrm{SO}_{2}$ columns are high and the sink (AOD) is low. For the $\mathrm{NO}_{2} / \mathrm{AOD}$ proxy, elevated values are also observed over the Johannesburg-Pretoria area while for the other proxies a local minimum occurs over these cities.

All the four satellite proxies show larger values at Elandsfontein than at Marikana, which is consistent with the results obtained for the in situ proxies. Based on the in situ results the $\mathrm{SO}_{2}$-related proxies are expected to predict $N_{\text {nuc }}$ at the time of the satellite overpass better than the other proxies. A comparison of the spatial patterns of each proxy calculated using satellite data in the vicinity of the in situ measurement stations shows that there is not very much difference between the spatial pattern of $\mathrm{SO}_{2}$ - and $\mathrm{NO}_{2}$-related proxies.

The propagation of relative uncertainty associated with the proxies using satellite data can be estimated by comparing the uncertainties related to each satellite parameter (Sect. 3) and the observed median values shown in Fig. 11. On the one hand, over background areas where both AOD and $\mathrm{SO}_{2}$ are low the $\mathrm{SO}_{2} \cdot \mathrm{UVB} / \mathrm{AOD}^{2}$ proxy can have an uncertainty of over $90 \%$. On the other hand, over source areas where both $\mathrm{NO}_{2}$ and AOD are slightly elevated the $\mathrm{NO}_{2}$ /AOD proxy would have an uncertainty of about $50 \%$. Generally over South Africa the uncertainty in satellite-based proxies is high, especially over areas where low values of $\mathrm{NO}_{2}, \mathrm{SO}_{2}$, and $\mathrm{AOD}$ are frequently observed.

\subsubsection{Comparison of satellite and in situ proxy components}

Before evaluating the performance of the proxies using satellite data, first the quality of the parameters used in these proxies should be examined. The CS/AOD comparison was discussed in Sect. 4.1. Here we compare satellite data for $\mathrm{NO}_{2}$, $\mathrm{SO}_{2}$ and UVB with in situ data at each of the measurement 
Table 2. Correlations between in-situ- and satellite-based proxies. The number of coincident observations is denoted with " $N$ ". Scatter plots for each of the case are provided as a Supplementary Material.

\begin{tabular}{|c|c|c|c|c|}
\hline Station & $\begin{array}{l}\left(\mathrm{NO}_{x} \text {-NO)/CS vs. }\right. \\
\mathrm{NO}_{2} / \mathrm{AOD}\end{array}$ & $\begin{array}{l}\mathrm{SO}_{2} / \mathrm{CS} \text { vs. } \\
\mathrm{SO}_{2} / \mathrm{AOD}\end{array}$ & $\begin{array}{l}\mathrm{SO}_{2} \cdot \mathrm{UVB} / \mathrm{CS}^{2} \text { vs. } \\
\mathrm{SO}_{2} \cdot \mathrm{UVB} / \mathrm{AOD}^{2}\end{array}$ & $\begin{array}{l}\text { Glob./CS }{ }^{2} \text { vs. } \\
\text { UVB/AOD }\end{array}$ \\
\hline Elandsfontein & $R^{2}=0.11, N=46$ & $R^{2}=0.20, N=41$ & $R^{2}=0.13, N=39$ & $R^{2}=0.30, N=52$ \\
\hline Marikana & $R^{2}=0.38, N=93$ & $R^{2}=0.005, N=76$ & $R^{2}=0.13, N=76$ & $R^{2}=0.22, N=117$ \\
\hline Botsalano & $R^{2}=0.004, N=16$ & $R^{2}=0.12, N=14$ & $R^{2}=0.30, N=14$ & $R^{2}=0.11, N=18$ \\
\hline
\end{tabular}

stations. The satellite data for each station are collected within a $12 \mathrm{~km}\left(\mathrm{NO}_{2}, \mathrm{SO}_{2}, \mathrm{UVB}\right)$ or a $3 \mathrm{~km}$ (AOD) radius from the station and the results are compared with hourly means of the in situ data extracted between 13:00 and 14:00 LT, i.e. \pm 30 min within the approximate satellite overpass.

The satellite $\mathrm{NO}_{2}$ column densities and the in situ $\mathrm{NO}_{x}$ $\mathrm{NO}$ concentrations are reasonably well correlated as are the satellite UVB irradiances and the global radiation measured at each station. The highest correlation for $\mathrm{NO}_{2}$ were obtained at Marikana $\left(R^{2}=0.55\right)$ and the lowest at Elandsfontein $\left(R^{2}=0.26\right)$. For UVB and global radiation the correlations were $0.61 \leq R^{2} \leq 0.77$. In Kulmala et al. (2011) a constant value was assumed for the satellite-based $\mathrm{SO}_{2}$ when defining the global proxy maps, because the $\mathrm{SO}_{2}$ product they used (middle tropospheric $\mathrm{SO}_{2}$ ) did not show a reasonable spatial pattern. In this study the middle-troposphere $\mathrm{SO}_{2}$ data were replaced by the OMI boundary layer product (Sect. 3), which improved the characterization of the $\mathrm{SO}_{2}$ spatial variation (Fig. 10). However, the relative uncertainty in the satellite-based $\mathrm{SO}_{2}$ remains still high, unless the data are averaged over a long time period/large spatial area. At all three stations a lower correlation between the satellite- and in-situ-based $\mathrm{SO}_{2}$ measurements was obtained than for the other source parameters; at Marikana there is practically no correlation. Similar results were obtained when the satelliteand in-situ-based proxies were compared (Table 2, figures in the Supplementary Material). Overall large differences exist between the satellite proxies and in situ proxies.

Since at Marikana and Elandsfontein the in situ data showed correlation between the $\mathrm{NO}_{x}-\mathrm{NO}$ and the $\mathrm{SO}_{2}$ concentrations, the satellite $\mathrm{NO}_{2}$ column density is also compared with the in situ $\mathrm{SO}_{2}$. Results show that in fact the OMI $\mathrm{NO}_{2}$ compares better with the in situ $\mathrm{SO}_{2}$ than the actual $\mathrm{OMI} \mathrm{SO}_{2}$ product. At Elandsfontein $R^{2}=0.25$ and at Marikana $R^{2}=0.31$, obtained between the satellite $\mathrm{NO}_{2}$ column and in situ $\mathrm{SO}_{2}$ concentration.

\subsubsection{Comparison of satellite-based proxies with $N_{\text {nuc }}$}

To further evaluate the performance of the satellite-based proxies, they are compared to the in situ $N_{\text {nuc }}$. Only data from Elandsfontein and Marikana are included in the comparison since the number of coincident $N_{\text {nuc }}$ and satellite proxy ob-
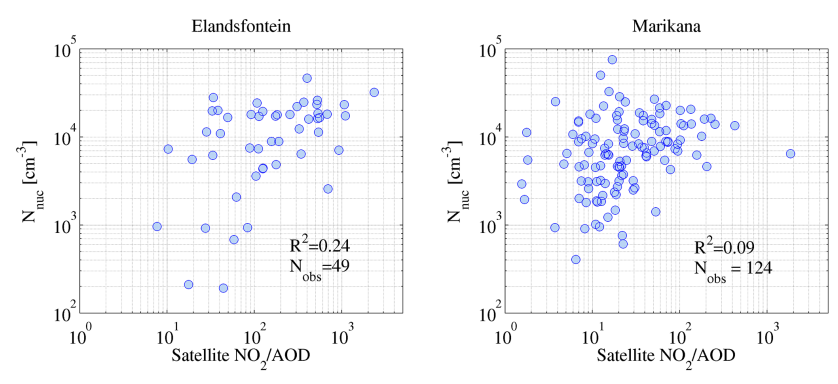

Figure 12. The comparison between the number concentration of nucleation mode particles and $\mathrm{NO}_{2}$ /AOD calculated from the satellite data at Marikana and at Elandsfontein stations. The number concentrations are $1 \mathrm{~h}$ averages (13:00-14:00 LT) representative of the satellite overpass time. It is noted that at Elandsfontein $N_{\text {nuc }}$ represents particles with $D_{\mathrm{p}} 10-30 \mathrm{~nm}$ and at Marikana particles with $D_{\mathrm{p}}<30 \mathrm{~nm}$. $N_{\text {obs }}$ denotes the number of coincident observations.

servations was too low at the other stations. As expected, neither of the two satellite-based $\mathrm{SO}_{2}$ proxies are able to predict $N_{\text {nuc }}$. Interestingly, the only case where weak correlation is obtained between a proxy using satellite data and $N_{\text {nuc }}$ is for $\mathrm{NO}_{2} / \mathrm{AOD}$ (Fig. 12). This result is very different than what is expected based on the comparison of the in situ proxies and $N_{\text {nuc }}$. In fact, the connection between $\mathrm{NO}_{2} / \mathrm{AOD}$ and $N_{\text {nuc }}$ is most probably related to the correlation between the satellite $\mathrm{NO}_{2}$ column density and the in situ $\mathrm{SO}_{2}$ concentration. If the source term in the $\mathrm{SO}_{2} \cdot \mathrm{UVB} / \mathrm{AOD}^{2}$ proxy was replaced by $\mathrm{NO}_{2} \cdot \mathrm{UVB}$, the correlation with $N_{\text {nuc }}$ at Elandsfontein would be $R^{2}=0.23$ and at Marikana would be $R^{2}=0.06$. This implies that over areas where $\mathrm{SO}_{2}$ and $\mathrm{NO}_{2}$ are affected by some common factors, e.g. emission sources, the satellite $\mathrm{NO}_{2}$ could be a better estimate for the source term than $\mathrm{SO}_{2}$.

\section{Conclusions}

This work explores the use of proxies using satellite data to obtain information on the concentration of nucleation mode aerosol particles $\left(N_{\text {nuc }}\right)$. These proxies have been formulated using relations derived from data on ground-based nucleation and precursor gases, which were simplified for the use of satellite data in Kulmala et al. (2011). The simplifications and associated assumptions are critically examined. In this study data were used over part of South Africa where 
ground-based observations are available from four experimental sites for comparison with both the satellite-based parameters used in the proxy formulations and for comparison of the proxies with ground-based measurements of the nucleation mode aerosol particle number concentrations. For the computation of the proxies, data from the A-train satellites are used. The $\mathrm{NO}_{2}, \mathrm{SO}_{2}$, and UVB radiation are obtained from the OMI instrument and AOD from the MODIS instrument. The $\mathrm{NO}_{2}$ and UVB data are the same as those used in Kulmala et al. (2011), but the AOD was upgraded to the newest collection $6,3 \mathrm{~km}$ product. Also, the $\mathrm{SO}_{2}$ product was changed to the planetary boundary layer product $(\mathrm{OMI} \mathrm{SO} 2$ PBL) that represents the total column values with a priori assumption that the emissions are mainly in the boundary layer. The satellite observations are also extensively compared with in situ data.

Based on the proxies derived from the in situ data it is expected that the $\mathrm{SO}_{2}$-related proxies would be the best predictors of $N_{\text {nuc }}$ within the study area at the time of the satellite overpass (13:00-14:00 LT). It is also noted that even though the in situ $\mathrm{NO}_{2} / \mathrm{CS}$ proxy did not do well in predicting $N_{\text {nuc }}$, a positive correlation between the $\mathrm{SO}_{2}$ and $\mathrm{NO}_{2}$ concentrations is found at the measurement stations (at 13:00-14:00 LT). The $R^{2}$ between in situ $\mathrm{SO}_{2} / \mathrm{CS}$ and $N_{\text {nuc }}$ is 0.22 and this value could be considered as some kind of "upper limit" for the satellite proxies, for which uncertainties are much higher than for the in situ proxies. Using ground-based data, Kulmala et al. (2011) reported that $\mathrm{SO}_{2}$ had only moderate influence on the performance of the $\mathrm{SO}_{2} \cdot \mathrm{UV} / \mathrm{CS}^{2}$ proxy in southern Finland. The overall correlation between this proxy and $N_{\text {nuc }}$ over South Africa was even lower $\left(R^{2}=0.13\right)$ than over southern Finland $\left(R^{2}=0.29\right)$, yet our results clearly indicate a strong influence of $\mathrm{SO}_{2}$ on the performance of the proxy. If the $\mathrm{SO}_{2}$ was excluded from the proxy, no correlation with in situ proxies and $N_{\text {nuc }}$ was found.

Kulmala et al. (2011) emphasized that the most crucial assumption in deriving the satellite-based proxies was the replacement of the CS with AOD. This assumption is further evaluated in the current study using several tests. A fundamental reason for differences between CS and AOD is the intrinsic dependence on different aerosol size ranges, with CS more sensitive to very small particles (smaller than about $200 \mathrm{~nm}$ ) and AOD more sensitive to particles larger than that. Yet, good correlation is obtained between measured scattering coefficients for dry aerosol and CS evaluated from collocated particle size distribution measurements. When the in situ scattering coefficients or CS are compared with collocated AOD measurements, the correlation decreases. This may be due to several effects. In particular the presence of elevated aerosol layers and/or large dust particle increases the AOD but does not affect the CS. However, overall the AOD is rather low $(<0.1)$ over the major part of the study area; this means that these values are also associated with substantial relative uncertainty, which needs to be accounted for when deriving the satellite-based proxies.

Even though the $\mathrm{OMI} \mathrm{SO}_{2}$ PBL data product showed a distinct improvement in describing the spatial patterns of $\mathrm{SO}_{2}$ as compared to the data set used in Kulmala et al. (2011), the satellite-based $\mathrm{SO}_{2}$ did not describe well the day-to-day variations at the measurement stations. In addition, the observed $\mathrm{SO}_{2}$ column values were often close to the noise level associated with a single column retrieval reported by Krotkov et al. (2008). The only relation between a satellite-based proxy and $N_{\text {nuc }}$ was obtained for $\mathrm{NO}_{2} / \mathrm{AOD}$ (at Elandsfontein $R^{2}=$ 0.24 and at Marikana $R^{2}=0.09$ ). The result is different than what was expected based on the in situ proxies. The most probable explanation is the positive correlation between the ground-based $\mathrm{NO}_{2}$ and $\mathrm{SO}_{2}$ concentrations within the study area. It is found that in fact the satellite $\mathrm{NO}_{2}$ column correlates better with in situ $\mathrm{SO}_{2}$ concentration than the satellite $\mathrm{SO}_{2}$ column, where no correlation was found.

Overall this study shows that the uncertainties related to the satellite products remain a major issue in this satellitebased proxy approach, especially over areas like South Africa, where the AOD and the $\mathrm{SO}_{2}$, and $\mathrm{NO}_{2}$ concentrations are generally relatively low. Throughout the whole study the relative uncertainties related to the satellite-based proxies were well above $50 \%$. For the $\mathrm{NO}_{2} / \mathrm{AOD}$ proxy the largest relative uncertainties were often related to AOD. Otherwise $\mathrm{SO}_{2}$ was clearly the most uncertain component in the proxies calculated using satellite data. Despite these uncertainties related to the satellite data, the in situ data did not do significantly better in predicting $N_{\text {nuc }}$ within our study area. This indicates that overall improvements in the formulation of the proxies are needed.

\section{The Supplement related to this article is available online at doi:10.5194/acp-15-4983-2015-supplement.}

Acknowledgements. This work is supported by Academy of Finland (1251427, 1139656, Finnish Centre of Excellence in Atmospheric Science 272041), European Research Council (ATMNUCLE), the European Aerosol Cloud Climate and Air Quality Interactions project (EUCAARI), and the ESA projects Aerosol-cci (ESA-ESRIN project AO/1-6207/09/I-LG) and ALANIS-Aerosols (contract no. 4200023053/10/I-LG, STSE-ALANIS AtmosphereLand Interactions Study Theme 3: Aerosols). Eskom and Sasol supplied logistical support for measurements at Elandsfontein, while the town council of Rustenburg supplied support to the measurement at Marikana. The $\mathrm{OMI} \mathrm{NO}_{2}, \mathrm{SO}_{2}$, and UV data were obtained from the NASA Mirador service maintained by Goddard Earth Sciences Data and Information Services Center (GES DISC). The OMI surface UV data were obtained from the NASA Aura Validation Data Center (AVDC). The MODIS Aqua data were provided by NASA LAADS Web, and the CALIPSO data were obtained from NASA Atmospheric Science Data Center (ASDC). 
Edited by: S. M. Noe

\section{References}

Beukes, P., Vakkari, V., van Zyl, P. G., Venter, A., Josipovic, M., Jaars, K., Tiitta, P., Kulmala, M., Worsnop, D., Pienaar, J., Virkkula, A., and Laakso L.: Source region plume characterisation of the interior of South Africa, as measured at Welgegund, Clean Air J., 23, 7-10, 2013.

Bucsela, E. J., Krotkov, N. A., Celarier, E. A., Lamsal, L. N., Swartz, W. H., Bhartia, P. K., Boersma, K. F., Veefkind, J. P., Gleason, J. F., and Pickering, K. E.: A new stratospheric and tropospheric $\mathrm{NO}_{2}$ retrieval algorithm for nadir-viewing satellite instruments: applications to OMI, Atmos. Meas. Tech., 6, 26072626, doi:10.5194/amt-6-2607-2013, 2013.

Burrows, J. P., Platt, U., and Borrell, P. (Eds.): The Remote Sensing of Tropospheric Composition from Space, 536 pp., SpringerVerlag Berlin Heidelberg, ISBN: 978-3-642-14790-6, p. 359313, doi:10.1007/978-3-642-14791-3, 2011.

Crippa, P., Spracklen, D., and Pryor, S. C.: Satellite-derived estimates of ultrafine particle concentrations over Eastern North America, J. Geophys. Res., 118, 9968-9981, 2013.

Fioletov, V. E., McLinden, C. A., Krotkov, N., Moran, M. D., and Yang, K.: Estimation of $\mathrm{SO}_{2}$ emissions using OMI retrievals, Geophys. Res. Lett., 38, L21811, doi:10.1029/2011GL049402, 2011.

Fuchs, N. A. and Sutugin, A. G.: Highly dispersed aerosol, in: Topics in current aerosol research (Part 2), edited by: Hidy, G. M. and Brock, J. R., Pergamon, New York, 1971.

Giannakaki, E., Pfüller, A., Korhonen, K., Mielonen, T., Laakso, L., Vakkari, V., Baars, H., Engelmann, R., Beukes, J. P., Van Zyl, P. G., Josipovic, M., Tiitta, P., Chiloane, K., Piketh, S., Lihavainen, H., Lehtinen, K. E. J., and Komppula, M.: One year of Raman lidar observations of free tropospheric aerosol layers over South Africa, Atmos. Chem. Phys. Discuss., 15, 1343 1384, doi:10.5194/acpd-15-1343-2015, 2015.

Hirsikko, A., Vakkari, V., Tiitta, P., Manninen, H. E., Gagné, S., Laakso, H., Kulmala, M., Mirme, A., Mirme, S., Mabaso, D., Beukes, J. P., and Laakso, L.: Characterisation of sub-micron particle number concentrations and formation events in the western Bushveld Igneous Complex, South Africa, Atmos. Chem. Phys., 12, 3951-3967, doi:10.5194/acp-12-3951-2012, 2012.

Hirsikko, A., Vakkari, V., Tiitta, P., Hatakka, J., Kerminen, V.-M., Sundström, A.-M., Beukes, J. P., Manninen, H. E., Kulmala, M., and Laakso, L.: Multiple daytime nucleation events in semi-clean savannah and industrial environments in South Africa: analysis based on observations, Atmos. Chem. Phys., 13, 5523-5532, doi:10.5194/acp-13-5523-2013, 2013

Holben, B., Eck, T. F., Slutsker, I., Tanre, D., Buis, J. P., Setzer, A., Vermote, E., Reagan, J. A., Kaufman, Y. J., Nakajima, T., Lavenu, F., Jankowiak, I., and Smirnov, A.: AERONET - A Federated Instrument Network and Data Archive for Aerosol Characterization, Rem. Sens. Environ., 66, 1-16, 1998.

IPCC, Intergovernmental Panel on Climate Change: Fifth Assessment Report: Climate Change, Cambridge University Press, Cambridge, United Kingdom and New York, NY, USA, 2013.
Kokhanovsky, A. A. and de Leeuw, G. (Eds.): Satellite Aerosol Remote Sensing over Land, Springer, Berlin, Germany, 2009.

Krotkov, N., Carn, S., Krueger A., Bhartia, P., and Yang, K.: Band residual difference algorithm for retrieval of $\mathrm{SO}_{2}$ from the Aura Ozone Monitoring Instrument (OMI), IEET T. Geosci. Rem., 44, 1259-1266, 2006

Krotkov, N., McClure, B., Dickerson, R., Carn, S., Li, C., Bhartia, P., Yang, K., Krueger, A., Li, Z., Levelt, P., Chen, H., Wang, P. and $\mathrm{Lu}, \mathrm{D}$.: Validation of $\mathrm{SO}_{2}$ retrievals from the Ozone Monitoring Instrument over NE China, J. Geophys. Res., 113, D16S40, doi:10.1029/2007JD008818, 2008.

Kulmala, M. and Kerminen, V.-M.: On the formation and growth of atmospheric nanoparticles, Atmos. Res., 90, 132-150, 2008.

Kulmala, M., Vehkamäki, H., Petäjä, T., Dal Maso, M., Lauri, A., Kerminen, V.-M., Birmili, W., and McMurry, P. H.: Formation and growth rates of ultrafine atmospheric particles: a review of observations, J. Aerosol Sci., 35, 143-176, 2004.

Kulmala, M., Petäjä, T., Mönkkönen, P., Koponen, I. K., Dal Maso, M., Aalto, P. P., Lehtinen, K. E. J., and Kerminen, V.-M.: On the growth of nucleation mode particles: source rates of condensable vapor in polluted and clean environments, Atmos. Chem. Phys., 5, 409-416, doi:10.5194/acp-5-409-2005, 2005.

Kulmala, M., Arola, A., Nieminen, T., Riuttanen, L., Sogacheva, L., de Leeuw, G., Kerminen, V.-M., and Lehtinen, K. E. J.: The first estimates of global nucleation mode aerosol concentrations based on satellite measurements, Atmos. Chem. Phys., 11, 10791-10801, doi:10.5194/acp-11-10791-2011, 2011.

Laakso, L., Laakso, H., Aalto, P. P., Keronen, P., Petäjä, T., Nieminen, T., Pohja, T., Siivola, E., Kulmala, M., Kgabi, N., Molefe, M., Mabaso, D., Phalatse, D., Pienaar, K., and Kerminen, V.-M.: Basic characteristics of atmospheric particles, trace gases and meteorology in a relatively clean Southern African Savannah environment, Atmos. Chem. Phys., 8, 4823-4839, doi:10.5194/acp-8-4823-2008, 2008.

Laakso, L., Vakkari, V., Virkkula, A., Laakso, H., Backman, J., Kulmala, M., Beukes, J. P., van Zyl, P. G., Tiitta, P., Josipovic, M., Pienaar, J. J., Chiloane, K., Gilardoni, S., Vignati, E., Wiedensohler, A., Tuch, T., Birmili, W., Piketh, S., Collett, K., Fourie, G. D., Komppula, M., Lihavainen, H., de Leeuw, G., and Kerminen, V.-M.: South African EUCAARI measurements: seasonal variation of trace gases and aerosol optical properties, Atmos. Chem. Phys., 12, 1847-1864, doi:10.5194/acp-12-1847-2012, 2012

Lamsal, L. N., Krotkov, N. A., Celarier, E. A., Swartz, W. H., Pickering, K. E., Bucsela, E. J., Gleason, J. F., Martin, R. V., Philip, S., Irie, H., Cede, A., Herman, J., Weinheimer, A., Szykman, J. J., and Knepp, T. N.: Evaluation of OMI operational standard $\mathrm{NO}_{2}$ column retrievals using in situ and surface-based $\mathrm{NO}_{2}$ observations, Atmos. Chem. Phys., 14, 11587-11609, doi:10.5194/acp14-11587-2014, 2014.

Lee, K. H., Li, Z., Kim, Y. J., and Kokhanovsky, A.: Atmospheric aerosol monitoring from satellite observations: a history of three decades, in: Atmospheric and biological environmental monitoring, Springer, the Netherlands, 2009.

Lehtinen, K. E. J., Korhonen, H., Dal Maso, M., and Kulmala, M.: On the concept of condensation sink diameter, Boreal Env. Res., 8, 405-411, 2003.

Levy, R. C., Mattoo, S., Munchak, L. A., Remer, L. A., Sayer, A. M., Patadia, F., and Hsu, N. C.: The Collection 6 MODIS aerosol 
products over land and ocean, Atmos. Meas. Tech., 6, 29893034, doi:10.5194/amt-6-2989-2013, 2013.

Mielonen, T., Levy, R. C., Aaltonen, V., Komppula, M., de Leeuw, G., Huttunen, J., Lihavainen, H., Kolmonen, P., Lehtinen, K. E. J., and Arola, A.: Evaluating the assumptions of surface reflectance and aerosol type selection within the MODIS aerosol retrieval over land: the problem of dust type selection, Atmos. Meas. Tech., 4, 201-214, doi:10.5194/amt-4-201-2011, 2011.

Mishchenko, M. I., Travis, L. D., and Lacis, A. A.: Scattering, Absorption, and Emission of Light by Small Particles. Cambridge University Press, Cambridge, 2002.

Petäjä, T., Mauldin, III, R. L., Kosciuch, E., McGrath, J., Nieminen, T., Paasonen, P., Boy, M., Adamov, A., Kotiaho, T., and Kulmala, M.: Sulfuric acid and $\mathrm{OH}$ concentrations in a boreal forest site, Atmos. Chem. Phys., 9, 7435-7448, doi:10.5194/acp9-7435-2009, 2009.

Petäjä, T., Vakkari, V., Pohja, T., Nieminen, T., Laakso, H., Aalto, P. P., Keronen, P., Siivola, E., Kerminen, V.-M., Kulmala, M., and Laakso, L.: Transportable Aerosol Characterization Trailer with Trace Gas Chemistry: Design, Instruments and Verification, Aerosol Air Qual. Res., 13, 421-435, 2013.

Schnelle-Kreis, J., Küpper, U., Sklorz, M., Cyrys, J., Briedé, J. J., Peters, A., and Zimmerman, R.: Daily measurements of organic compounds in ambient particulate matter in Augsburg, Germany: new aspects on aerosol sources and aerosol related health effects, Biomarkers, 14 (SI), 39-44, 2009.

Seaton, A., MacNee, W., Donaldson, K., and Godden, D.: Particulate air pollution and acute health effects, The Lancet, 345, 176178, 1995.

Tanskanen, A., Krotkov, N. A., Herman, J. R., and Arola, A.: Surface Ultraviolet Irradiance From OMI, IEEE Trans. Geosci. Remote Sens., 44, 1267-1271, 2006.
Utell, M. J. and Frampton, M. W.: Acute Health Effects of Ambient Air Pollution: The Ultrafine Particle Hypothesis, J. Aerosol Med. Pulm. Drug. Deliv., 13, 355-359, 2000.

Vakkari, V., Laakso, H., Kulmala, M., Laaksonen, A., Mabaso, D., Molefe, M., Kgabi, N., and Laakso, L.: New particle formation events in semi-clean South African savannah, Atmos. Chem. Phys., 11, 3333-3346, doi:10.5194/acp-11-3333-2011, 2011.

Vakkari, V., Beukes, J. P., Laakso, H., Mabaso, D., Pienaar, J. J., Kulmala, M., and Laakso, L.: Long-term observations of aerosol size distributions in semi-clean and polluted savannah in South Africa, Atmos. Chem. Phys., 13, 1751-1770, doi:10.5194/acp13-1751-2013, 2013.

Venter, A. D., Vakkari, V., Beukes, J. P., van Zyl, P. G., Laakso, H., Mabaso, D., Tiitta, P., Josipovic, M., Kulmala, M., Pienaar, J. J., and Laakso. L.: An air quality assessment in the industrialised western Bushveld Igneous Complex, South Afric S. Afr. J. Sci., 108, 1059, doi:10.4102/sajs.v108i9/10.1059, 2012.

Virkkula, A., Backman, J., Aalto, P. P., Hulkkonen, M., Riuttanen, L., Nieminen, T., dal Maso, M., Sogacheva, L., de Leeuw, G., and Kulmala, M.: Seasonal cycle, size dependencies, and source analyses of aerosol optical properties at the SMEAR II measurement station in Hyytiälä, Finland, Atmos. Chem. Phys., 11, 4445-4468, doi:10.5194/acp-11-4445-2011, 2011.

Winker, D. M., Hunt, W. M., and McGill, M. J.: Initial performance assessment of CALIOP, Geophys. Res. Lett., 34, L19803, doi:10.1029/2007GL030135, 2007.

York, D., Evensen, N., Martinez, M., and Delgado, J.: Unified equations for the slope, intercept, and standard errors of the best straight line, Am. J. Phys., 72, 367-375, 2004. 